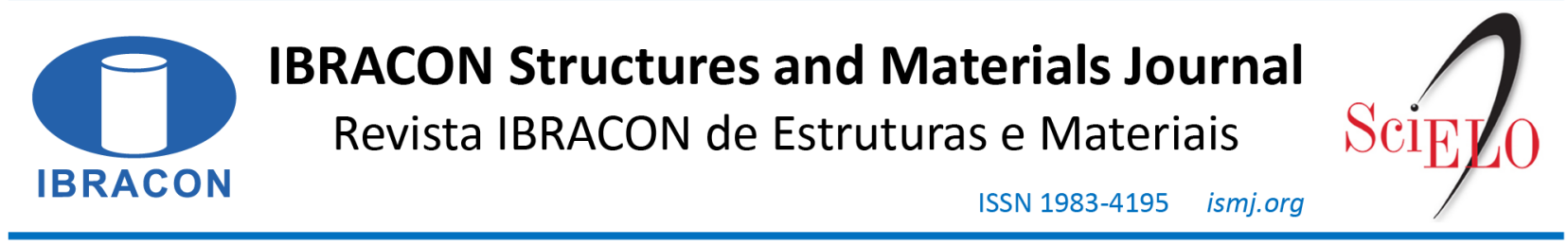

ORIGINAL ARTICLE

\title{
Shear friction capacity of self-consolidating concrete
}

\section{Resistência atrito cisalhamento do concreto autoadensável}

\author{
Gustavo Savaris $^{\mathrm{a}}$ \\ Roberto Caldas de Andrade Pinto ${ }^{\mathrm{b}}$ (D)
}

${ }^{a}$ Universidade Tecnológica Federal do Paraná - UTFPR, Coordenação de Engenharia Civil, Toledo, PR, Brasil

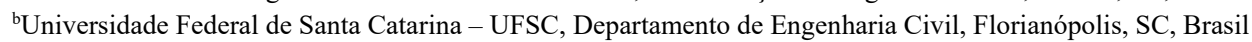

Received 23 December 2018

Accepted 18 May 2020

\begin{abstract}
An experimental research was developed to evaluate shear transfer in self-consolidating. Three concrete mixes were prepared, one conventional and two self-consolidating, differing on the proportion of the coarse and fine aggregate used. Nine push-off specimens, containing steel reinforcement passing through the shear plane, were tested, to evaluate the ultimate shear stress and shear plane displacements. Shear strength of self-consolidating concrete specimens were higher than conventionally vibrated concrete. The experimental results were compared to the shear strength estimated by literature and code based equations, yielding conservative results of these equations for both types of concrete, especially the models that disregard the compressive strength of concretes.
\end{abstract}

Keywords: self-consolidating concrete. shear friction. aggregate interlock. push-off.

\begin{abstract}
Resumo: Um programa experimental foi desenvolvido para avaliar o atrito cisalhamento no concreto autoadensável. Três misturas de concreto foram preparadas, uma convencional e duas autoadensáveis, diferenciadas pela proporção de agregados miúdo e graúdo utilizada. Nove exemplares para ensaios do tipo push-off, contendo armadura transversal ao plano de cisalhamento, foram ensaiados para avaliar a tensão cisalhante última e os deslocamentos do plano de cisalhamento. A resistência ao cisalhamento do concreto autoadensável foi superior aos de concreto convencionalmente vibrado. Os resultados experimentais foram comparados com estimativas calculadas com equações da literatura e de normas de dimensionamento, demonstrando estas equações serem conservadoras para os dois tipos de concreto, especialmente em modelos que desconsideram a resistência à compressão do concreto.
\end{abstract}

Palavras-chave: concreto autoadensável. atrito cisalhamento. engrenamento do agregado. push off.

How to cite: G. Savaris and R. C. A. Pinto, "Shear friction capacity of self-consolidating concrete," Rev. IBRACON Estrut. Mater., vol. 14, no. 1, e14102, 2021, https://doi.org/10.1590/S1983-41952021000100002

\section{INTRODUCTION}

The shear transfer consists on different components that contribute to the shear resistance in reinforced concrete structures, involving the adhesion originated from a chemical bond between the cement paste and aggregates, friction between the interfaces of a crack, the aggregate interlock, the dowel effect caused by the reinforcement that is placed across the interfaces and external clamping force on the concrete [1]-[5].

Evaluating connections in precast concrete buildings, Birkeland and Birkeland [1] proposed the Equation 1 to determine the ultimate shear capacity across an interface, as well as potential cracks, for monolithic concrete, assuming that shear strength is proportional to reinforcement ratio placed across the interface and yield strength of reinforcement.

$$
\tau_{u}=1.7 \rho_{v} f_{y}
$$

Corresponding author: Gustavo Savaris. E-mail: gsavaris@utfpr.edu.br

Financial support: This research was supported by the Coordination for the Improvement of Higher Education Personnel (CAPES) and Federal University of Technology - Paraná.

Conflict of interest: Nothing to declare. 
Where $\tau_{\mathrm{u}}=$ ultimate shear stress $(\mathrm{MPa}) ; \rho_{\mathrm{v}}=$ reinforcement ratio $\left(\mathrm{A}_{\mathrm{s}} / \mathrm{A}_{\mathrm{c}}\right) ; \mathrm{f}_{\mathrm{y}}=$ yield strength of reinforcing $(\mathrm{MPa})$.

The push-off test is a nonstandard, but widely recognized, test used in the testing of shear in concrete. Using this kind of test Hofbeck et al. [2] demonstrated the influence of the cohesion of the material particles and of the friction between the surfaces of the cracks in push-off tests. Concrete failure on the shear plane was dependent on the combination of normal and shear stresses. Thus, the authors proposed that the failure envelope resembled to the MohrCoulomb rupture failure criterion.

Evaluating the results from several experimental push-off tests, with and without pre-cracking of the shear plane, Mattock [3] quantified the ultimate shear stress considering the Mohr-Coulomb rupture failure criteria, as shown in Equation 2 (in MPa). The first term of the equation corresponds to the cohesion of material particles, estimated at 2.76 $\mathrm{MPa}$, while the second term is related to the friction between the surfaces of the cracks, considering the externally applied normal stress acting across the shear plane and a coefficient of friction equal to 0.8 :

$\tau_{u}=2.76+0.8\left(\rho_{v} f_{y}+\sigma_{n}\right) \leq 0.3 f_{c}$

Where $f_{c}=$ compressive strength of the concrete $(\mathrm{MPa}) ; \sigma_{\mathrm{n}}=$ externally applied normal stress across the shear plane (MPa).

A theoretical model for the transfer of forces through the crack interfaces, considering that cracks originate in the mortar phase, was developed by Walraven [4]. This model considers concrete as a combination of coarse aggregate, with high strength and stiffness, and mortar with low strength and stiffness. Vecchio and Collins [5] used this model to determine the ultimate tensile strength of reinforced concrete elements submitted to shear and normal stresses, considering the crack width, the stress of the crack surfaces, the compressive strength of the concrete and the maximum aggregate size employed, proposing the Equation 3:

$$
\begin{aligned}
& \tau_{u}=0.18 \tau_{\text {cimax }}+1.64 \sigma_{n}-0.82 \frac{\sigma_{n}^{2}}{\tau_{\text {cimax }}} \\
& \tau_{\text {cimax }}=\frac{\sqrt{f_{c}}}{\left(0.31+\frac{24 w}{a_{g}+16}\right)}
\end{aligned}
$$

Where $\tau_{\text {cimax }}=$ maximum shear stress on the shear plane in the cracked concrete $(\mathrm{MPa}) ; \mathrm{w}=$ crack width $(\mathrm{mm})$; $\mathrm{a}_{\mathrm{g}}=$ maximum coarse aggregate size $(\mathrm{mm})$.

Walraven et al. [6] related the ultimate shear strength to the compressive strength of concrete, to the transverse reinforcement ratio, and to the steel yield strength, resulting in Equation 5, which was obtained by statistical analysis of a large number of experimental tests:

$\tau_{u}=0.878 f_{c}^{0.406}\left(\rho_{v} f_{y}\right)^{0.167 f_{c}^{0.303}}$

In the discussion of Walraven et al. [6], Mattock [7] presented a modified expression, that related the frictional shear resistance to compressive strength of concrete, obtained from push-off tests using concrete with compressive strength lower than $45 \mathrm{MPa}$ :

$$
\tau_{u}=0.467 f_{c}^{0.545}+0.8\left(\rho_{v} f_{y}+\sigma_{n}\right) \leq 0.3 f_{c}
$$

Sonnenberg et al. [8] performed an experimental program using a shear box and compared the results with the Mohr-Coulomb frictional hypothesis, demonstrating that for normal stresses greater than $0.15 \mathrm{f}_{\mathrm{c}}$, a Mohr-Coulomb model with cohesion of $0.22 \mathrm{f}_{\mathrm{c}}$ and a friction angle of $35^{\circ}$ could be used to predict the results. 
Lin et al. [9] presented the results of an experimental program with push-off and direct shear tests aiming to reveal the components of shear resistance. Based on results the authors defined that, for initially uncracked reinforced concrete, the shear components: friction between concrete and aggregate interlock, cement paste-aggregate adhesion, shear dilation and dowel action corresponds to $20 \%, 25 \%, 40 \%$ and $15 \%$ of the ultimate shear transfer capacity, respectively.

Self-consolidating concrete (SCC) is a concrete that can flow under its own weight, completely filling formwork and achieving full compaction, even in the presence of congested reinforcement. The mix proportioning of SCC requires smaller aggregate content and higher ratios of fine aggregate volume, besides mineral additions, and the use of superplasticizer. These mixture characteristics can affect the shear strength mechanisms and several researches have been carried out to evaluate the shear strength of self-consolidating concrete (SCC) and compare to conventional concrete, but there is not a consensus.

Sells et al. [10] performed push-off tests with conventional and self-consolidating concretes, varying coarse aggregate type and coarse aggregate to fine aggregate volume ratios, finding that concrete type (CC or SCC) and coarse aggregate content makes little difference to the aggregate interlock capability of the concrete, resulting similar shear strengths.

However, the results presented by Desnerck et al. [11] demonstrated higher shear strength of self-consolidating concrete than the conventional concrete, even though SCC contains a lower coarse aggregate volume fraction. The increase on shear strength was associated to an improve on the mortar matrix, due to the addition of fine materials to the concrete mixture, such as filler and silica fume.

Kim et al. [12] performed push-off tests to investigate the influence of SCC aggregate and paste volumes on the shear capacity and these results were compared with those obtained from similar CC samples. The test results confirmed that the volume of aggregate influences the contribution of aggregate interlock to the shear capacity, so that SCC samples presented lower maximum shear stresses at a given crack width as compared to the CC samples.

Savaris and Pinto [13] investigated the influence of the reduction in volume content and the nominal size of coarse aggregate on the SCC and CC shear strength. Six concrete mixes were used for casting beams with longitudinal reinforcement and without shear reinforcement under four-point loading condition. The results demonstrated a lower shear resistance of self-consolidating concrete beams, caused mainly due to the reduced aggregate size.

Current design codes do not take account of the particularities of self-consolidating concrete mixtures and possible effects on shear strength. American building code requirements for structural concrete ACI 318 [14] estimates the shear friction resistance in a plane with or without a crack through Equation 7, based on Birkeland and Birlekand theory [1]. ACI 318 considers the existence of transverse reinforcement perpendicular to the surface with a coefficient of friction $(\mu)$ of 1.4 for concrete produced with aggregate of normal specific weight and placed monolithically.

$V_{n}=\mu A_{v f} f_{y}$

Where $\mathrm{A}_{\mathrm{vf}}=$ area of reinforcement crossing the assumed shear plane to resist shear $\left(\mathrm{mm}^{2}\right)$.

The Canadian code for design of concrete structures, CAN A23.3 [15], considers that for a crack occurring along the shear plane, the relative displacement of this plane must be resisted by cohesion and friction, maintained by the reinforcement crossing the crack. The shear strength across the assumed shear plane shall be computed by the Equation 8 for normal weight concrete placed monolithically and with reinforcement perpendicular to the crack:

$\tau_{n}=0.6 \sqrt{\sigma f_{c}}$

$\sigma=\rho_{v} f_{y}+\frac{N}{A_{g}}$

Where $\mathrm{N}$ is the unfactored permanent load perpendicular to the shear plane, positive for compression and negative for tension, and $\mathrm{A}_{\mathrm{g}}$ is the gross area of the concrete section.

The equations presented at codes described above are based on test results with conventional concrete. Considering that it is important to evaluate the shear strength to better understand how changes in concrete composition can influence the shear transfer mechanism, this paper presents the results of an experimental investigation dealing with the shear strength of self-consolidating and conventionally vibrated concrete under push-off tests. The literature and code-based 
design equations in predicting the shear strength are also evaluated and their estimates are compared to the experimental results.

\section{EXPERIMENTAL PROGRAM}

To evaluate the shear friction strength of self-consolidating concrete, an experimental program was performed. Nine reinforced concrete specimens, all of them with the same dimensions and reinforcement ratio were submitted to pushoff tests. The concrete mixtures differ on their workability/fluidity and their coarse aggregate volume fraction in the mixture.

\subsection{Mix design and materials}

Three concrete mixes were used, one conventional vibrated concrete and two self-consolidating concrete. Table 1 presents the mixture proportions. Conventional concrete specimens were denoted as CC and self-consolidating concrete specimens were denoted as $\mathrm{SC}$ followed by $\mathrm{N}$ for mixture with the same coarse aggregate content as conventional concrete or $\mathrm{R}$ for mixture with coarse aggregate content reduced by $30 \%$.

Table 1. Mix proportions $\left(\mathrm{kg} / \mathrm{m}^{3}\right)$.

\begin{tabular}{cccccccc}
\hline $\begin{array}{c}\text { Concrete } \\
\text { mixture }\end{array}$ & Cement & Filler & $\begin{array}{c}\text { Natural } \\
\text { sand }\end{array}$ & Artificial sand & $\begin{array}{c}\text { Coarse } \\
\text { aggregate }\end{array}$ & Water & Superplasticizer \\
\hline CC & 385.2 & - & 418.5 & 417.4 & 964.6 & 200.3 & - \\
\hline SCN & 385.2 & 214.7 & 312.9 & 312.0 & 964.6 & 200.3 & 0.87 \\
\hline SCR & 385.7 & 215.1 & 456.5 & 455.3 & 676.0 & 200.6 & 1.15 \\
\hline
\end{tabular}

High early-strength cement CP-V ARI, similar to ASTM Type III, was used for all mixtures. Fine aggregate consisted of a mix of 50\% natural quartz sand, and 50\% crushed granite stone, with the former material being much finer than the latter. A granite coarse aggregate with nominal maximum size of $19.0 \mathrm{~mm}$ was used. In self-consolidating concrete mixtures, fine aggregate was partially replaced by limestone filler to promote higher viscosity. A polycarboxylate-based superplasticizer was used in the SC mixtures.

Table 2 presents the fresh properties and 28-day compressive strength of the concrete mixtures investigated. The traditional slump test was conducted for the conventional concrete, while slump flow, L-Box and V-Funnel tests were conducted for self-consolidating concretes. The compressive strengths were determined using three cylindrical specimens $(10 \times 20 \mathrm{~cm})$ for each mixture.

Table 2. Fresh and hardened properties of self-consolidating and conventional vibrated mixtures.

\begin{tabular}{cccccc}
\hline Concrete mixture & Slump (mm) & Slump flow $(\mathbf{m m})$ & V-funnel (s) & L-Box & f, $\mathbf{m}(\mathbf{M P a})$ \\
\hline CC & 105 & - & - & - & 36.3 \\
SCN & - & 665 & 19.63 & 0.87 & 41.2 \\
\hline SCR & - & 690 & 11.94 & 0.87 & 47.0 \\
\hline
\end{tabular}

\subsection{Specimens details}

The dimensions and reinforcement details of the tested specimens are shown in Figure 1. Three specimens were cast for each concrete mixture, being denoted by letters A, B or C.

Ribbed steel bars of $5 \mathrm{~mm}$ in diameter (CA-60) were used as closed stirrups through the shear plane, corresponding to a transverse reinforcement ratio of $0.181 \%$, and an additional reinforcement $\mathrm{L}$-shaped with bars of $10 \mathrm{~mm}$ in diameter (CA-50) and $5 \mathrm{~mm}$ (CA-60) closed stirrups were used to prevent premature failure outside the shear plane during load application, as can be seen in Figure 1.The steel bars were tested in tension, resulting in yield stresses of 538 and $658 \mathrm{MPa}$ for CA-50 and CA-60 reinforcing bars, respectively.

The shear plane cross section was reduced to $100 \mathrm{~mm}$ x $220 \mathrm{~mm}$, as detailed in Figure 1, by inserting thin wood sheets of $10 \mathrm{~mm}$ in width, prior to casting, at each side of shear plane. Three push-off specimens were cast for each batch. Mechanical vibration was used only for the conventional concrete mix. After $24 \mathrm{~h}$, the specimens and cylinders were demolded, placed under plastic canvas, and moistened during the first seven days, after which they remained in laboratory conditions. 

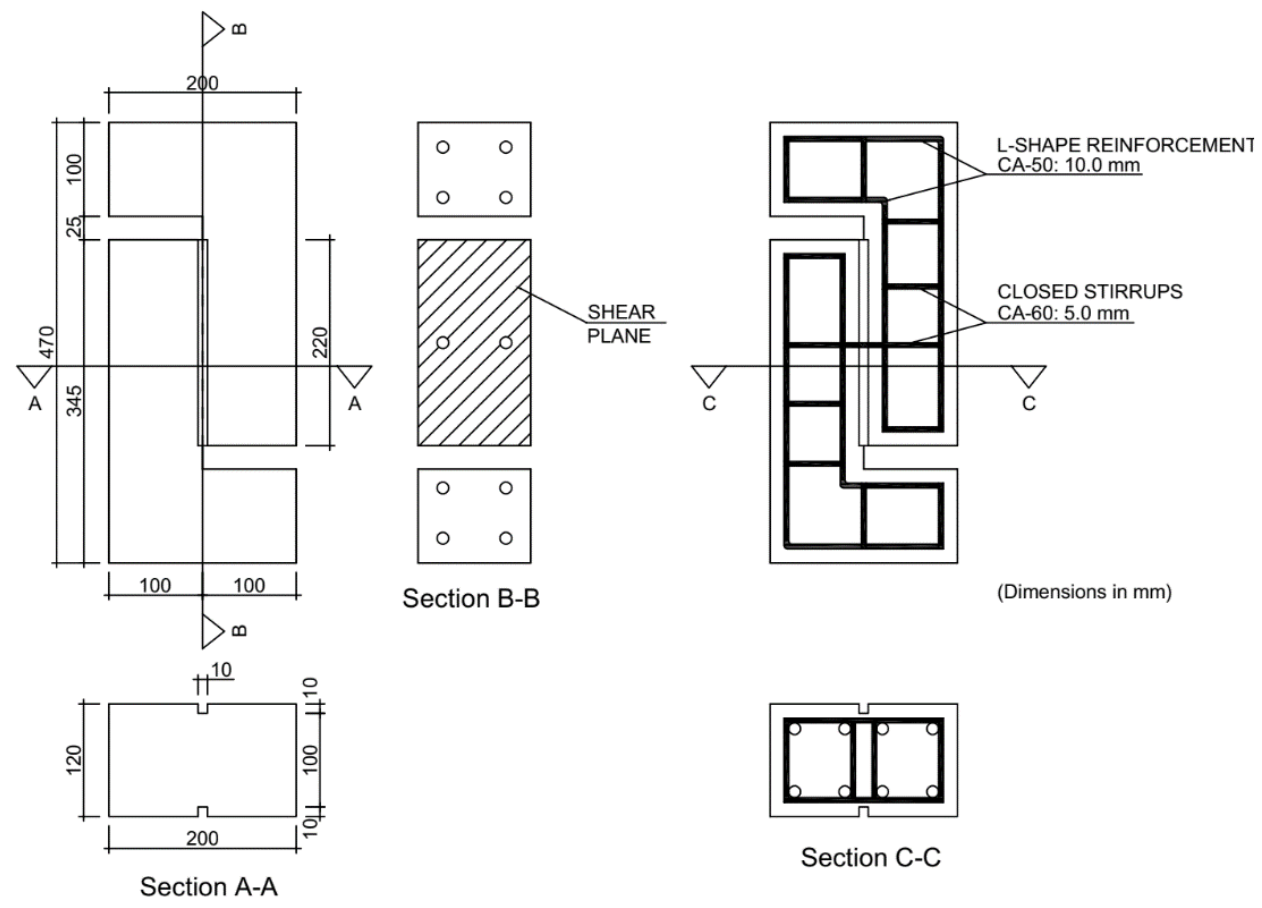

Figure 1. Specimens dimensions and reinforcement details.

\subsection{Test instrumentation and procedure}

Push-off tests were conducted at 28 days after casting. Vertical loading was applied using a hydraulic actuator with a capacity of $500 \mathrm{kN}$, at an average load rate of $50 \mathrm{~N} / \mathrm{s}$ (Figure 2), until the specimen rupture. The specimens were instrumented using four $50 \mathrm{~mm}$ stroke linear variable displacement transducers, two of them installed vertically to measure the vertical displacement of the shear plane, whereas the others horizontally to measure crack width.

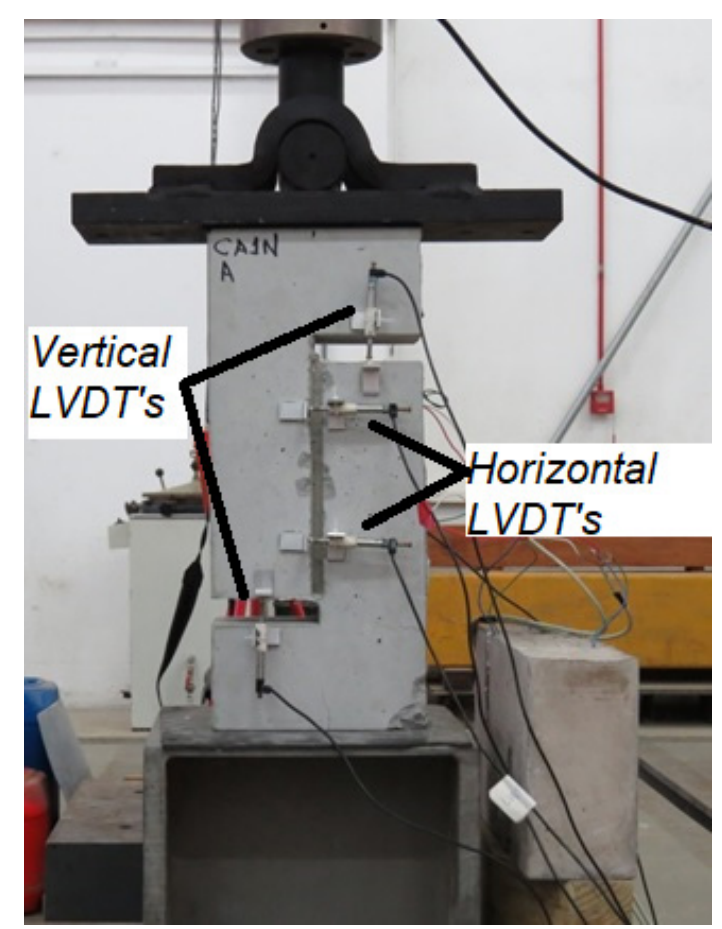

Figure 2. Specimen set-up and instrumentation. 
The steel bars that crossed the shear plane in the specimens denoted by letter " $A$ " were instrumented using strain gauges located approximately $10 \mathrm{~mm}$ from the shear plane (Figure 3). This distance was necessary to ensure that the strain gauge would not be damaged during the test. The load cell installed in the hydraulic actuator, the displacement transducers and the strain gauges were connected to a data acquisition system.

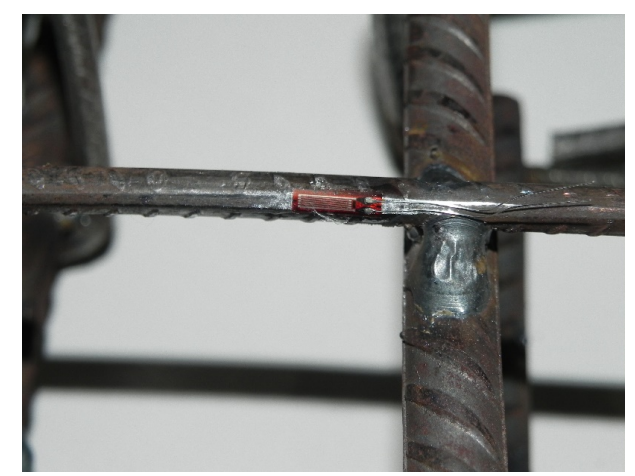

Figure 3. Steel bar instrumentation using strain gauge.

\section{RESULTS AND DISCUSSION}

\subsection{General cracking and failure behavior}

In general, a similar behavior was observed for all push-off tests. The shear friction mechanism could be divided into three distinct stages, similar as showed by Harries et al. [16], and illustrated in Figure 4, for the three specimens of each concrete type.
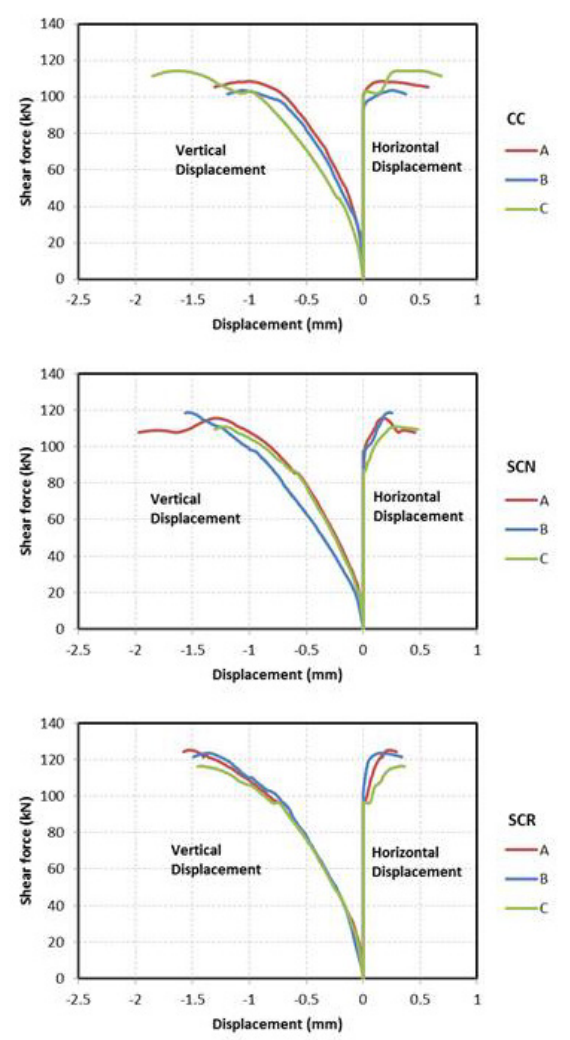

Figure 4. Shear plane displacements measured during loading. 
The first stage, from the beginning of the loading until the formation of the crack in the shear plane, was characterized by vertical displacement, due to concrete deformation under compression, and small horizontal displacements, with the applied load being resisted only by the concrete. The strength at this stage would be the result of the cohesion forces before cracking.

The second stage began with the formation of the crack in the shear plane, when an increase in the reinforcement strain was observed, as showed at Figure 5, with shear force around $80 \mathrm{kN}$. At this stage, shear forces were initially resisted by the friction between the crack surfaces, resulting from the surface roughness of the interface and by the normal force generated by the reinforcement, which restricted crack opening. Nonetheless, with the increase of reinforcement strain, the crack opening increased and a subsequent reduction of aggregate interlock occurred, until the ultimate resistance was reached.



Figure 5. Reinforcement strain measured during loading.

At final stage, an increase of the vertical and horizontal displacements was observed with the decrease of the applied load, indicating the yield of the reinforcement, resulting in the rupture of one or both reinforcement bars that crossed the shear plane (Figure 6).

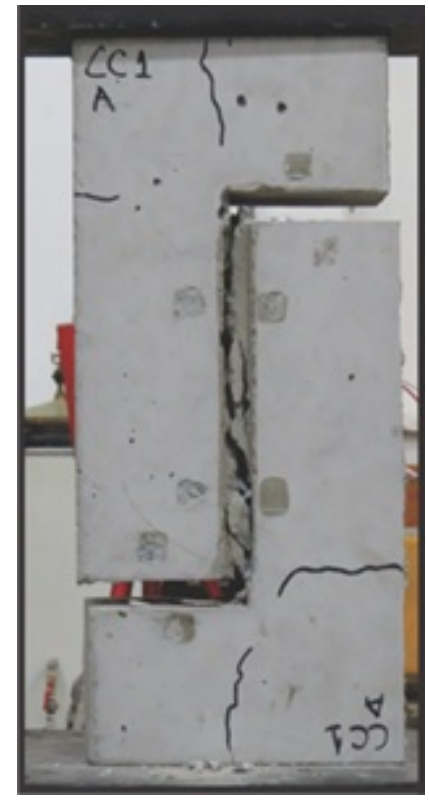

Figure 6. Rupture of specimen CC-A. 


\subsection{Shear resistance}

Table 3 presents the ultimate shear stresses $\left(\tau_{u}\right)$ at the shear plane area $(100 \mathrm{~mm} \times 220 \mathrm{~mm})$ for each specimen, as well as the average stresses and the standard deviation for each mixture. To take into account differences in compressive strength among the concrete mixtures, normalized shear stresses $\left(\tau_{\text {un }}\right)$ were calculated according to Equation 10, being also shown in Table 3.

Table 3. Ultimate shear stresses

\begin{tabular}{|c|c|c|c|c|c|}
\hline Concrete mixture & Specimen & $\tau_{\mathrm{u}}(\mathbf{M P a})$ & $\tau_{\mathrm{u}, \mathrm{m}}(\mathbf{M P a})$ & $\begin{array}{c}\text { Standard } \\
\text { deviation (MPa) } \\
\end{array}$ & $\tau_{\text {un }}\left(\mathbf{M P a}^{0.5}\right)$ \\
\hline & A & 4.94 & & & 0.82 \\
\hline \multirow[t]{3}{*}{$\mathrm{CC}$} & B & 4.71 & 4.95 & 0.25 & 0.78 \\
\hline & $\mathrm{C}$ & 5.20 & & & 0.86 \\
\hline & A & 5.25 & & & 0.82 \\
\hline \multirow[t]{3}{*}{$\mathrm{SCN}$} & B & 5.39 & 5.23 & 0.18 & 0.84 \\
\hline & $\mathrm{C}$ & 5.04 & & & 0.79 \\
\hline & A & 5.69 & & & 0.83 \\
\hline \multirow[t]{2}{*}{ SCR } & B & 5.62 & 5.53 & 0.21 & 0.82 \\
\hline & $\mathrm{C}$ & 5.29 & & & 0.77 \\
\hline
\end{tabular}

$\tau_{u n}=\frac{\tau_{u}}{\sqrt{f_{c}}}$

The statistical F-test for equality of means of the normalized shear stress of the mixtures was performed. The results indicated that there was not a significant difference between these values at a $95 \%$ confidence level.

The normalized shear stress vs. reinforcement strain plots for the specimens are shown in Figure 7, where it can be verified that before cracking, the three mixtures presented similar shear strength. After cracking it seems to exist a little time interval until the cracks begins to increase its opening, when the aggregate interlock mechanisms occur. The CC presented higher normalized shear stress until cracking, around $0.7 \mathrm{MPa}^{0.5}$, probably due to higher aggregate interlock, considering that this concrete had lower content of fine materials. Despite self-consolidating concrete presented normalized shear stress between 0.55 and $0.6 \mathrm{MPa} \mathrm{a}^{0.5}$ when the crack started to open, a higher reinforcement strain after cracking was observed, that may be associated to a better bond of self-consolidating concrete to the reinforcement bars [17] [18]. This possible improve in bond strength would increase the compression forces transverse to the shear plane with a consequently higher friction between the surfaces, which would result in similar ultimate shear stresses to all concretes.

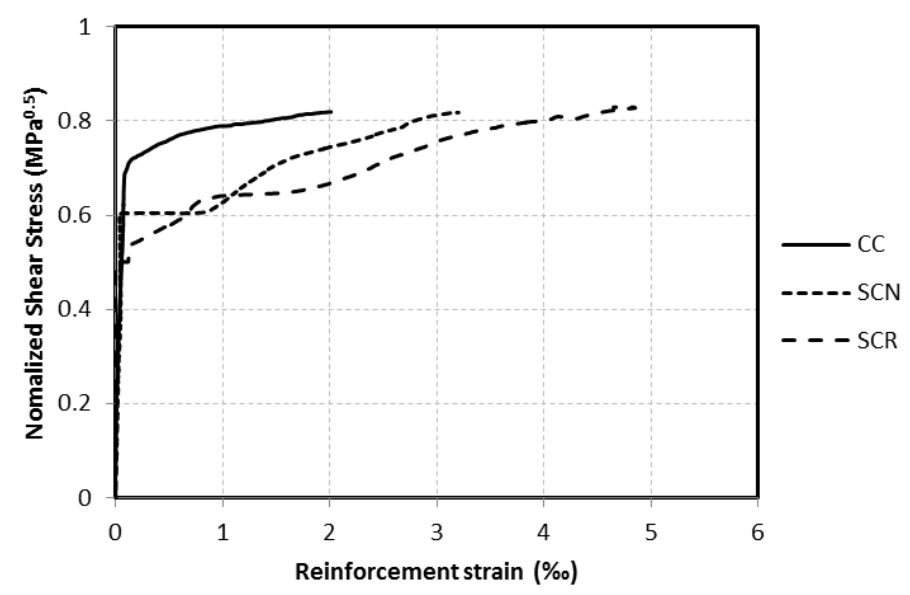

Figure 7. Normalized shear stress vs. reinforcement strain. 
Considering that the specimens used in this study presented low transverse reinforcement ratio, this result may indicate that the increase in the transverse reinforcement ratio may result in higher shear strength for self-consolidating concrete, due to a better bond to the reinforcement, increasing the compression force transverse to the shear plane and consequently higher friction between the surfaces.

\subsection{Vertical displacement and cracking width}

Table 4 shows the average vertical displacements of shear plane and the crack widths measured at ultimate normalized stresses. Although the ultimate normalized shear stresses presented similar results, small variations in the vertical displacements and in the crack width values were observed. Comparing mean values, SCC mixtures presented higher vertical displacements than the CC mix, probably because of its higher amount of fine material, but more samples must be tested to allow a statistical analysis.

Table 4. Average vertical displacements and crack width at ultimate normalized stress.

\begin{tabular}{ccccccc}
\hline $\begin{array}{c}\text { Concrete } \\
\text { mixture }\end{array}$ & $\boldsymbol{\tau}_{\mathbf{u n}}\left(\mathbf{M P a}^{\mathbf{0 . 5}}\right)$ & $\boldsymbol{\tau}_{\mathbf{u n}, \mathbf{m}}\left(\mathbf{M P a}^{\mathbf{0 . 5}}\right)$ & $\boldsymbol{\Delta}_{\mathbf{u}}(\mathbf{m m})$ & $\boldsymbol{\Delta}_{\mathbf{u}, \mathbf{m}}(\mathbf{m m})$ & $\mathbf{W}_{\mathbf{u}}(\mathbf{m m})$ & $\mathbf{w}_{\mathbf{u}, \mathbf{m}}(\mathbf{m m})$ \\
\hline & 0.82 & & 0.989 & & 0.167 & \\
\hline $\mathrm{CC}$ & 0.78 & 0.82 & 1.056 & 1.23 & 0.255 & 0.24 \\
\hline & 0.86 & & 1.641 & & 0.301 & \\
\hline $\mathrm{SCN}$ & 0.82 & & 1.302 & & 0.296 & \\
\hline & 0.84 & 0.81 & 1.541 & 1.35 & 0.234 & 0.28 \\
\hline $\mathrm{SCR}$ & 0.79 & & 1.22 & & 0.295 & \\
\hline & 0.83 & & 1.523 & & 0.332 & \\
\hline & 0.82 & 0.81 & 1.367 & 1.44 & 0.164 & 0.28 \\
\hline
\end{tabular}

Kim et al. [12] and Harries et al. [16] demonstrated that shear strength reduces when the volume of aggregate size is reduced in concretes and this reduction has been attributed to a lower aggregate interlock in SCC. However, in this work the three mixtures showed similar normalized shear stresses for crack widths of $0.10 \mathrm{~mm}$ and $0.15 \mathrm{~mm}$, as presented in Table 5. As discussed before, similar shear strength may be associated to a higher bond to the reinforcing bars in self-consolidating concrete, that would increase the compressive force applied by the reinforcement to the crack surfaces, increasing shear transfer by friction, and therefore, compensating the lower aggregate interlock. This effect was also observed in Savaris and Pinto [19] were self-consolidating beams with stirrups presented similar shear strength to conventional concrete, compensating lower shear strength presented by beams without stirrups.

Table 5. Normalized shear stresses at crack width of 0.10 and $0.15 \mathrm{~mm}$.

\begin{tabular}{ccccc}
\hline \multirow{2}{*}{$\begin{array}{c}\text { Concrete } \\
\text { mixture }\end{array}$} & Specimen & \multicolumn{3}{c}{$\boldsymbol{\tau}$ (MPa) } \\
\cline { 3 - 5 } & $\mathrm{A}$ & 0.81 & $\mathbf{w}=\mathbf{0 . 1 0} \mathbf{~ m m}$ & $\mathbf{w}=\mathbf{0 . 1 5} \mathbf{~ m m}$ \\
\hline $\mathrm{CC}$ & $\mathrm{B}$ & 0.72 & 0.77 & 0.82 \\
\hline & $\mathrm{C}$ & 0.78 & & 0.73 \\
\hline $\mathrm{SCN}$ & $\mathrm{A}$ & 0.78 & 0.74 & 0.81 \\
\hline & $\mathrm{B}$ & 0.75 & & 0.80 \\
\hline & $\mathrm{C}$ & 0.71 & 0.74 & 0.79 \\
\hline $\mathrm{SCR}$ & $\mathrm{A}$ & 0.77 & 0.76 & 0.80 \\
\hline & $\mathrm{B}$ & 0.81 & & 0.82 \\
\hline
\end{tabular}


The relationship between reinforcement stresses, calculated based on measured strains, with measured crack widths is plotted in Figure 8 for all mixtures. The tested specimens showed a low variation on reinforcement stresses for crack width close to $0.1 \mathrm{~mm}$.

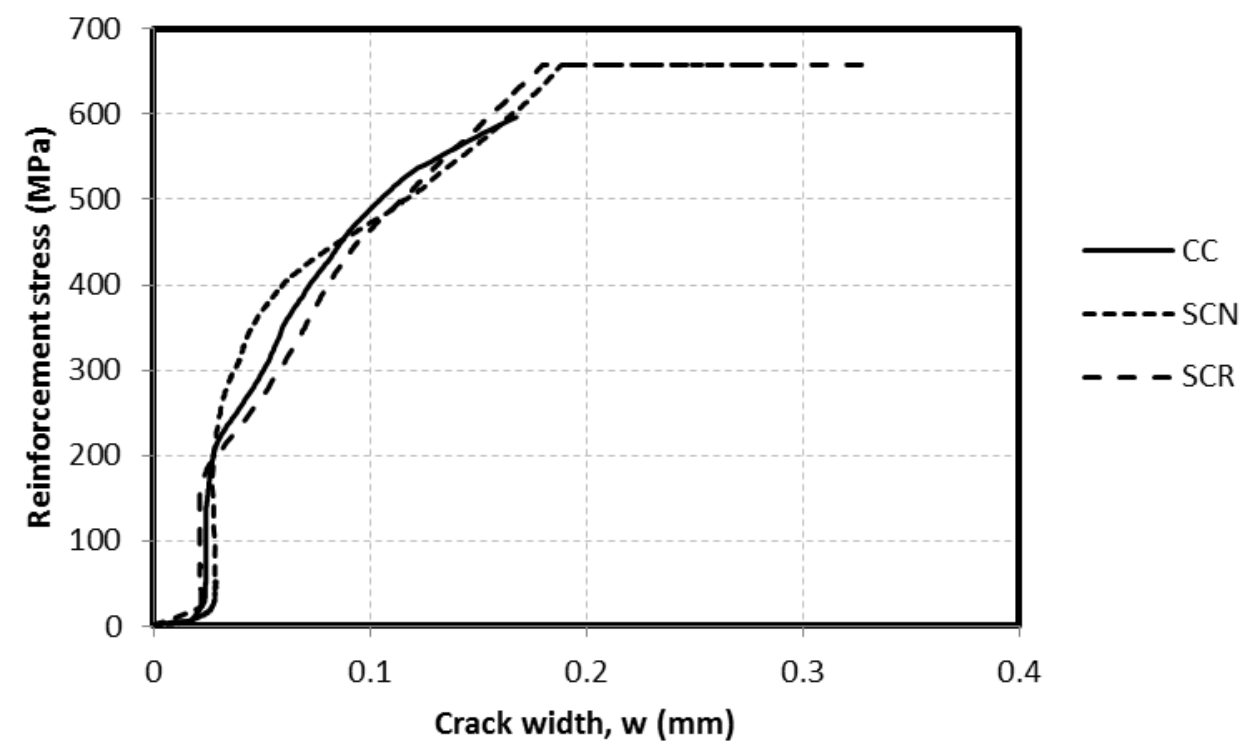

Figure 8. Reinforcement stresses vs. crack width.

Figures 9 to 11 show the relationship between shear forces and crack widths for all specimens. Also, the theoretical shear forces resisted by the cohesion of concrete and by the reinforcement are presented. As proposed by Harries et al. [16], the shear force resisted by the reinforcement was calculated from the reinforcement strains, measured during the test, assuming a coefficient of friction ( $\mu$ ) equal to 1.4. The theoretical shear stress component resisted by the cohesion of concrete consisted of the subtraction of the shear force resisted by reinforcement from the total shear force applied. The vertical straight line indicates the crack width corresponding to the ultimate shear force and the horizontal line indicates the shear force corresponding to yielding of the reinforcement.

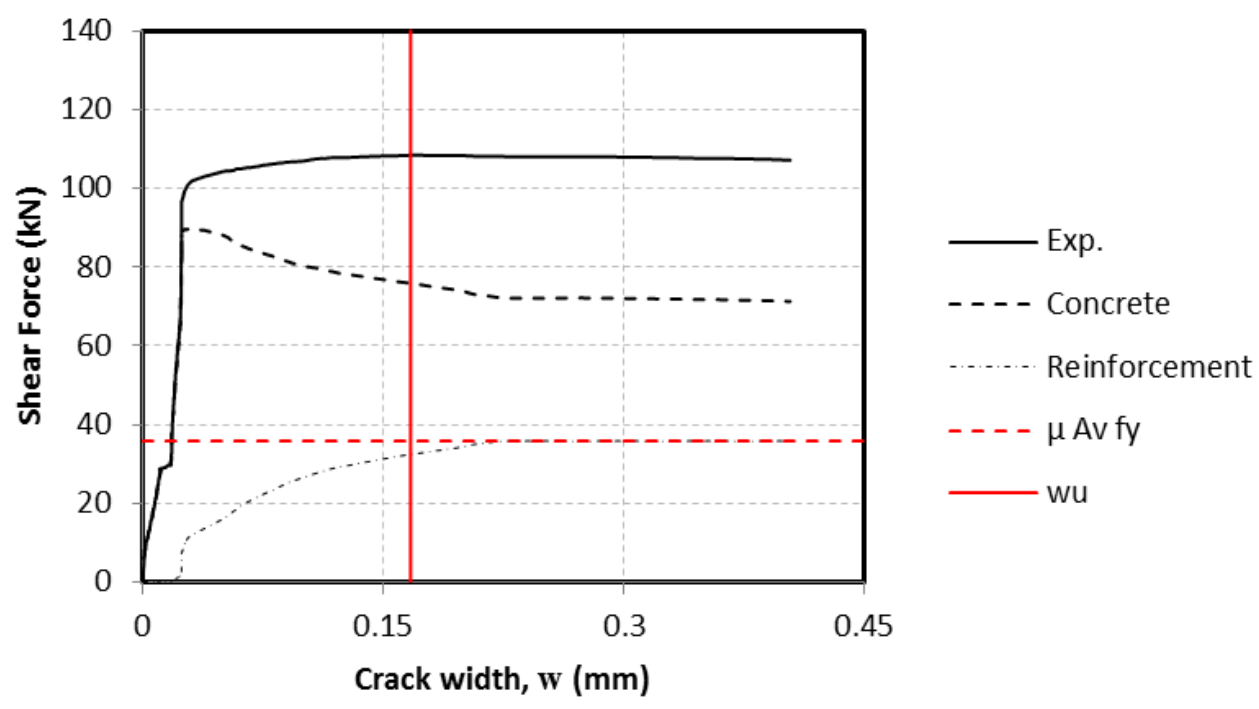

Figure 9. Experimental and theoretical shear strengths of CC-A specimen. 




Figure 10. Experimental and theoretical shear strengths of SCN-A specimen.

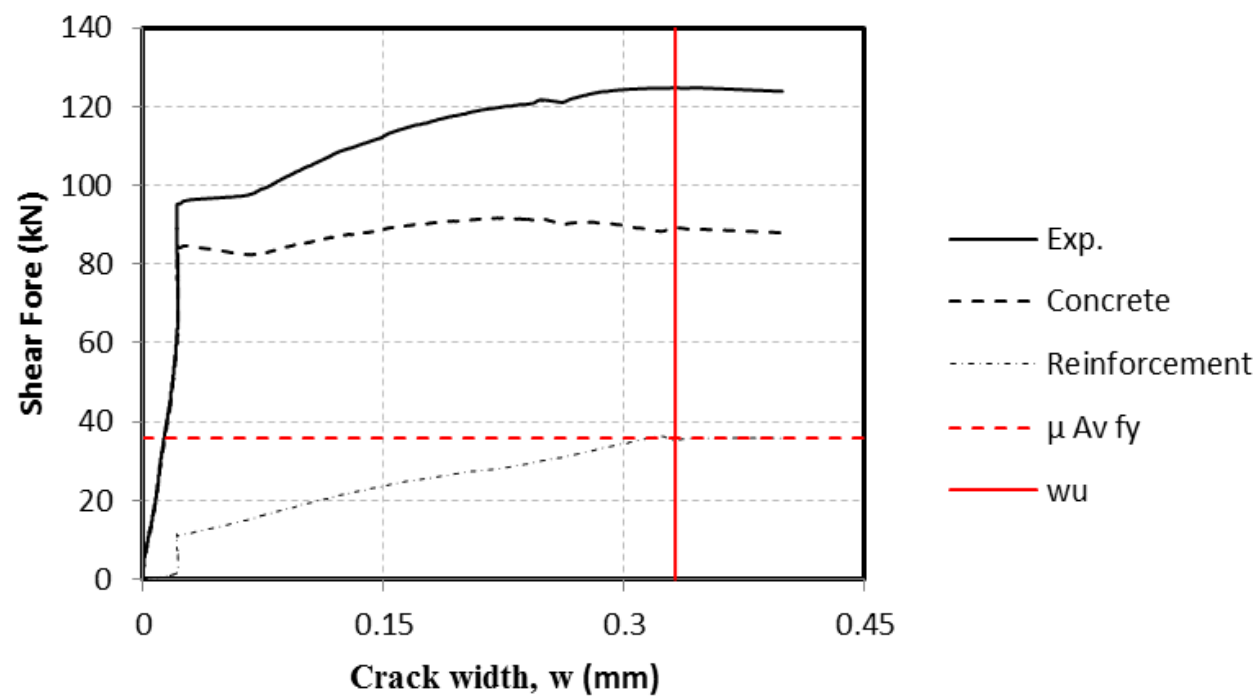

Figure 11. Experimental and theoretical shear strengths of SCR-A specimen.

From Figures 9 to 11 it can be observed that there was a distinct behavior between the CC and SCC mixes. In CC specimen, the compression force generated by the reinforcement after crack formation did not increase the total shear force resisted; instead the total shear remain approximately constant which led to a decrease in the cohesion forces (as can be seen by the decrease in the dashed lines). This behavior may have happened since as the crack opened, the aggregate interlock forces decreased while reinforcement strain increased. On the other hand, the SCC mixes showed an increase of the shear forces proportional to the resistance attributed to the reinforcement while the cohesion forces remained constant (as can be seen by the almost no variation on the dashed lines). This latter behavior justifies the observed largest post-cracking shear resistance of the SCC mixes. 


\subsection{Comparisons of experimental and theoretical shear strength}

Table 6 shows the experimental results and the estimates based on equations proposed in the literature by Birkeland and Birkeland [1], Mattock [3], Vecchio and Collins [5], Walraven et al. [6] and Mattock [7], (Equations 1, 2, 3, 5 and 6, respectively).

Table 6. Experimental ultimate stress and estimates based on literature equations.

\begin{tabular}{ccccccc}
\hline $\begin{array}{c}\text { Concrete } \\
\text { mixture }\end{array}$ & $\tau_{\mathrm{u}, \text { exp }}(\mathbf{M P a})$ & $\begin{array}{c}\text { Birkeland and } \\
\text { Birkeland [1] } \\
(\mathbf{M P a})\end{array}$ & $\begin{array}{c}\text { Mattock [3] } \\
(\mathbf{M P a})\end{array}$ & $\begin{array}{c}\text { Vecchio and } \\
\text { Collins [5] } \\
(\mathbf{M P a})\end{array}$ & $\begin{array}{c}\text { Walraven et al. [6] } \\
(\mathbf{M P a})\end{array}$ & $\begin{array}{c}\text { Mattock [7] } \\
(\mathbf{M P a})\end{array}$ \\
\hline $\mathrm{CC}$ & 4.95 & & & 4.11 & 4.07 & 4.24 \\
\hline $\mathrm{SCN}$ & 5.23 & 1.98 & 3.69 & 4.14 & 4.30 & 4.48 \\
\hline $\mathrm{SCR}$ & 5.53 & & & 4.31 & 4.55 & 4.74 \\
\hline
\end{tabular}

(1) Calculated considering crack width measured at ultimate shear stress and compression force perpendicular to shear plane related to reinforcement yield strength.

The equations presented ultimate shear stress estimates lower than the experimental results. This lower estimate is a consequence of their formulation, since they resulted mainly from experimental tests with pre-cracked specimens, in which the strength attributed to cohesion is lower than the specimens tested here.

Comparing the performance among these equations, it can be observed that Birkeland and Birkeland [1] presented the most conservative values, justified by a simplified model that considers only the friction coefficient and the transverse reinforcement ratio, while the equation proposed by Walraven et al. [6] presents less conservative results than the other models evaluated, even disregarding the portion resisted by the concrete cohesion.

Even though the equation proposed by Vecchio and Collins [5] considers aggregate size, crack width and compression force perpendicular to the crack plane, its estimates were still lower than the experimental values.

Since the ultimate shear stress was influenced by the compressive strength of the mixes, the equations proposed by Walraven et al. [6] and by Mattock [7], which considered this concrete property, fitted best to the experimental results than the others, with ratio ranges between 0.75 and 0.90 .

The ACI and CSA based design equations to estimate the ultimate shear friction resistances of experimental selfconsolidating and conventional concrete were also evaluated. Table 7 shows the experimental results and those calculated using Equations 7 and 8, corresponding to ACI 318 and CAN A23.3, respectively, and the ratio between these values.

Table 7. Ultimate shear strength - experimental results and code predictions.

\begin{tabular}{|c|c|c|c|c|c|}
\hline $\begin{array}{l}\begin{array}{l}\text { Concrete } \\
\text { mixture }\end{array} \\
\end{array}$ & $\tau_{\mathrm{u}, \exp }(\mathrm{MPa})$ & ACI 318 [14] (MPa) & $\begin{array}{c}\text { CAN A23.3 [15] } \\
\text { (MPa) }\end{array}$ & $\mathrm{ACI} / \tau_{\mathrm{u}, \exp (\mathrm{MPa})}$ & CAN $/ \tau_{\mathrm{u}, \exp }(\mathrm{MPa})$ \\
\hline $\mathrm{CC}$ & 4.95 & & 3.90 & 0.34 & 0.79 \\
\hline $\mathrm{SCN}$ & 5.23 & 1.67 & 4.16 & 0.32 & 0.80 \\
\hline SCR & 5.53 & & 4.44 & 0.30 & 0.80 \\
\hline
\end{tabular}

In general, CAN A23.3 [15] presented fewer conservative values with an estimated value near 0.80 of the experimental one. This better approximation is due since it considers the cohesion of the particles, associated to the concrete compressive strength, the friction between the surfaces and the transverse reinforcement ratio for monolithically concreted specimens. ACI 318 [14], however, presented the most conservative values due to its simple approach, which considers only the friction between surfaces, with a friction coefficient lower than the one proposed by the original authors.

\section{CONCLUSIONS}

The shear friction strength of conventional and self-consolidating concretes produced with different volume fraction of aggregate in the mixes were compared in this paper. The analysis of the experimental results obtained in concrete specimens submitted to push-off tests led to the following conclusions: 
- The tested specimens showed the same failure mode, regardless the differences on the concrete mixtures, with a crack formation in the shear plane, followed by vertical displacement of this plane and crack opening, resulting in rupture of the transverse reinforcement.

- Self-consolidating concrete mixtures with reduced coarse aggregate content showed lower shear cracking strength, which may have been caused by the replacement of fine aggregate by limestone filler and the reduction of coarse aggregate content resulting in a reduction of aggregate interlock.

- The ultimate shear stresses of the self-consolidating concrete mixes were slightly higher than the one for the conventional concrete mix, however, when the variation of concretes compressive strength were considered, the normalized shear stress of the mixtures indicated that there was not a significant difference between these values.

- Considering that the specimens tested had low reinforcement ratio, self-consolidating concrete mixes may present higher shear strength compared to conventional concrete when used higher transverse reinforcement ratio. This possible increase in shear strength may be due to the higher bond of self-consolidating concrete to reinforcement, raising the compression force perpendicular to shear plane and increasing friction between the crack surfaces.

- The ultimate shear stresses equations proposed in the literature that consider the concrete compressive strength provided estimates of around $80 \%$ of the experimental results, while the numerical models that disregard the cohesion between the concrete particles or the contribution of the transversal reinforcement presents estimates around $40 \%$ of experimental results.

\section{ACKNOWLEDGEMENTS}

The authors gratefully acknowledge the Coordination for the Improvement of Higher Education Personnel (CAPES), the Federal University of Santa Catarina and the Federal University of Technology - Paraná for their great support.

\section{REFERENCES}

[1] P. W. Birkeland, and H. W. Birkeland, "Connections in precast concrete construction," J. Am. Concr. Inst., vol. 63, no. 3, pp. 345$368,1966$.

[2] J. A. Hofbeck, I. O. Ibrahim, and A. H. Mattock, "Shear transfer in reinforced concrete," J. Am. Concr. Inst., vol. 66, no. 2, pp. 119$128,1969$.

[3] A. H. Mattock, "Shear transfer in concrete having reinforcement at an angle to the shear plane," ACI SP-42: Shear in Reinforced Concrete, vol. 1, pp. 17-42, 1974.

[4] J. C. Walraven, "Aggregate interlock: a theoretical and experimental analysis," Doctoral thesis, Technische Hogeschool Delft, The Netherlands, 1980.

[5] F. J. Vecchio, and M. P. Collins, "The modified compression field theory for reinforced concrete elements subject to shear," ACI J., vol. 83, pp. 219-231, 1986.

[6] J. C. Walraven, J. Frenay, and A. Pruijssers, "Influence of concrete strength and load history on the shear friction capacity of concrete members," PCI J., vol. 32, no. 1, pp. 66-84, 1987.

[7] A. H. Mattock, "Reader comments of paper Influence of concrete strength and load history on the shear friction capacity of concrete members," PCI J., vol. 33, no. 1, pp. 165-166, 1988.

[8] A. M. C. Sonnenberg, R. Al-Mahaidi, and G. Taplin, "Behaviour of concrete under shear and normal stresses," Mag. Concr. Res., vol. 55, no. 4, pp. 367-372, 2003.

[9] F. Lin, H. Lu, and Y. Dong, "Component model for shear transfer in reinforced concrete," Mag. Concr. Res., vol. 68, no. 15, pp. 755767, 2016., http://dx.doi.org/10.1680/jmacr.15.00269.

[10] E. Sells, J. J. Myers, and J. S. Volz, “Aggregate interlock push-off test results of Self-Consolidating Concrete (SCC) for use in infrastructure elements," in Proc. ISEC-7, Honolulu, Hawaii, 2013, http://dx.doi.org/10.3850/978-981-07-5354-2.

[11] P. Desnerck, G. De Schutter, and L. Taerwe, "Shear friction of reinforced self-consolidating concrete members," in ACI Special Publication 261-9, Farmington Hills, Michigan, 2009, pp. 133-141.

[12] Y. H. Kim, M. B. D. Hueste, D. Trejo, and D. B. H. Cline, "Shear characteristics and design for high-strength self-consolidating concrete," J. Struct. Eng., vol. 136, no. 8, pp. 989-1000, 2010, http://dx.doi.org/10.1061/(ASCE)ST.1943-541X.0000194.

[13] G. Savaris, and R. C. A. Pinto, "Influence of coarse aggregate on shear resistance of self-consolidating concrete beams," IBRACON Struct. Mater. J., vol. 10, no. 1, pp. 30-52, 2017, http://dx.doi.org/10.1590/S1983-41952017000100003.

[14] American Concrete Institute, Building code requirements for structural concrete and commentary, ACI 318R-14, 2014.

[15] Canadian Standards Association, Design of concrete structures, CAN A23.3, 2004. 
[16] K. A. Harries, G. Zeno, and B. Shahrooz, "Toward an improved understanding of shear friction behavior," ACI Struct. J., vol. 109, no. 6, pp. 835-844, 2012.

[17] A. A. A. Hassan, K. M. A. Hossain, and M. Lachemi, "Strength, cracking and deflection performance of large-scale selfconsolidating concrete beams subjected to shear failure," Eng. Struct., vol. 32, pp. 1262-1271, 2010, http://dx.doi.org/10.1016/j.engstruct.2010.01.002.

[18] T. J. Looney, M. Arezoumandi, J. S. Volz, and J. J. Myers, "An experimental study on bond strength of reinforcing steel in selfconsolidating concrete international," J. Concr. Struct. Mater., vol. 6, no. 3, pp. 187-197, 2012, http://dx.doi.org/10.1007/s40069012-0017-9.

[19] G. Savaris, and R. C. A. Pinto, "Experimental investigation on shear resistance of self-consolidating concrete beams," IBRACON Struct. Mater. J., vol. 12, no. 6, pp. 1305-1326, 2019, http://dx.doi.org/10.1590/S1983-41952019000600005.

Author contributions: GS: conceptualization, methodology, experimental results, formal analysis, writing; RCAP: conceptualization, supervision, formal analysis, writing.

Editors: Jose Tadeu Balbo, José Luiz Antunes de Oliveira e Sousa, Guilherme Aris Parsekian. 